\title{
特 集＼cjkstart膠原病：診断と治療の進歩
}

\section{トピックス}

\section{I． 新しい検査の意義と使い方 \\ 1. 抗核抗体}

高崎 芳成

要旨

抗核抗体 (ANA) は細胞の核成分に対する自己抗体の総称で, 膠原病を中心とする自己免疫疾患で高 率に検出される. 特異な疾患および病像との関連, さらに疾患活動性との相関を認めるものもあり, 日 常診療の場において有用な情報を提供する.ANAの測定には多くの異なる方法があるが,その結果を的 確に解釈するためには, 個々の抗体の特性を良く理解した上で, 各症例の臨床症状を勘案しながら最終 的な判断をする必要がある.

〔日内会誌 $96 ： 2124 \sim 2131 ， 2007 〕$

Key words : antinuclear antibody (ANA), antoantigen, connective tissue disease, antoantibody, diagnosis

はじめに

抗核抗体 (ANA) は，有核細胞の核成分に対 する自己抗体の総称で, 全身性エリテマトーデ ス (SLE)をはじめとする膠原病類縁疾患を有す る患者で高率に検出される ${ }^{1,2)}$. その対応抗原は, DNA， RNAなどの核酸と蛋白に分類されこれ らに対する抗体の中には特定の疾患や病像と相 関するものも多く, 診断や予後の予測に有用な 情報を提供する。 また，抗体によってはその抗 体価と疾患の活動性に相関が認められるものも あり，活動性の評価や治療の指標としても有用 で, 日常診療の場で重要な位置を占めている ${ }^{1,2}$. これらANAを検出するには, 多くの方法がある が, 抗体や目的に応じて適切な方法を選択し, 検査を進める必要がある。 また, その結果の解

たかさき よしなり：順天堂大学膠原病内科
釈を的確に行うためには, 個々の検出方法や抗 体の特性を理解し, 対象となる症例の臨床像を よく勘案することが求められる.

本稿では各ANAの特性や検出方法, さらにそ の臨床的意義について解説する.

\section{ANAの種類と構造}

表に主として検出される疾患別に, 各ANA (一部は抗細胞質抗体)の対応抗原の構造, その 抗体の出現率, さらに相関する病像を示す. ANA の対応抗原は大きくわけてDNAやRNAなどの核 酸と蛋白に分類され，さらに蛋白はクロマチン を構成する主成分であるヒストンと, 生理的食 塩水に溶けやすいことから可溶性核抗原 (ENA) とも呼ばれている非ヒストン酸性核蛋白に分類 される ${ }^{1,2)}$.これらの抗原はDNAやヒストンで構 成されるクロマチンに結合していたり，ENA のようにその間の核質に存在したり，さらにリ 
表. 各種自己抗体の対応抗原の構造と関連疾患 - 病像

\begin{tabular}{|c|c|c|c|c|}
\hline \multirow{2}{*}{ 自己抗原 } & \multicolumn{2}{|r|}{ 構造 } & \multirow{2}{*}{ 出現頻度 } & \multirow{2}{*}{ 関連病像 } \\
\hline & 核酸 & 蛋白 & & \\
\hline \multicolumn{5}{|c|}{ 全身性エリテマトーデス（SLE） } \\
\hline dsDNA & DNA & & $50 \sim 80 \%$ & 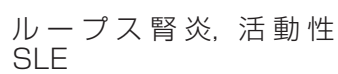 \\
\hline $\mathrm{Sm}$ & $\begin{array}{l}\text { U1, U2, U4-6 } \\
\text { RNA }\end{array}$ & $\begin{array}{l}\text { 200KD, 150KD, } \\
68 K D, A, B / B^{\prime} \\
\text { B", C, D, E, F, G }\end{array}$ & $15 \sim 30 \%$ & $\begin{array}{l}\text { CNS ループス, ループス } \\
\text { 腎炎, 抗U1RNP抗体陽性 }\end{array}$ \\
\hline $\mathrm{Ki}$ & & 32KD & $15 \sim 25 \%$ & 持続性関節炎, 乾燥症候群 \\
\hline リボゾーム $P^{*}$ & $\begin{array}{l}\text { 28S, 18S, 5.8S, } \\
\text { 5S-rRNA }\end{array}$ & $\begin{array}{l}38 \mathrm{KD}(\mathrm{PO}), 19 \mathrm{KD} \\
(\mathrm{Pl}), 17 \mathrm{KD}(\mathrm{P} 2)\end{array}$ & $10 \%$ & CNS ループス（精神症状） \\
\hline PCNA & DNA & $34 K D$ & $<5 \%$ & $\begin{array}{l}\text { CNS ループス, 血小板減 } \\
\text { 少, ループス腎炎 }\end{array}$ \\
\hline $\begin{array}{c}\text { ヒストン } \\
\text { 強皮症 (SSc) }\end{array}$ & DNA & $\mathrm{H} 1, \mathrm{H} 2 \mathrm{~A}, \mathrm{H} 2 \mathrm{~B}, \mathrm{H} 3, \mathrm{H} 4$ & $40 \sim 70 \%$ & $\begin{array}{l}\text { LE 細胞, 薬浏誘発性ルー } \\
\text { プス }\end{array}$ \\
\hline $\begin{array}{l}\text { トポイソメラーゼ I } \\
\text { (Scl-70) }\end{array}$ & DNA & $\begin{array}{l}\text { 100KD (70-90KDの分 } \\
\text { 解産物) }\end{array}$ & $20 \sim 30 \%$ & び漫性皮膚硬化，肺線維症 \\
\hline セントロメア & DNA & $\begin{array}{l}17 K D \text { (CENP-A), 80KD } \\
\text { (B), 140KD (C), 50KD } \\
\text { (D), 312KD (E), } \\
\text { 367KD (F), 95KD (G) }\end{array}$ & $10 \sim 15 \%$ & $\begin{array}{l}\text { 限 局 型皮膚硬化, } \\
\text { Raynaud 現象, PBC, 乾 } \\
\text { 燥症候群, 慢性甲状腺炎 }\end{array}$ \\
\hline RNA polymerase II & DNA（転写時） & $\begin{array}{l}\text { 240K, 220K, 145Kの } \\
\text { 各蛋白集合体 }\end{array}$ & $<5 \%$ & び漫性皮膚硬化, 強皮症腎 \\
\hline RNA polymerase II & DNA（転写時） & $\begin{array}{l}\text { 155K, 138K の各蛋白集 } \\
\text { 合体 }\end{array}$ & $<5 \%$ & び漫性皮膚硬化, 強皮症腎 \\
\hline \multicolumn{5}{|l|}{ 核小体抗原 } \\
\hline U3 RNP & U3 RNA & $34 K D$ & $3 \sim 6 \%$ & 肺高血圧，骨格筋障害 \\
\hline NOR 90 & DNA & 90KD, 86KD & $<5 \%$ & \\
\hline Th/To & 7-2/8-2 RNA & $38 K D$ & $<5 \%$ & 限局型皮膚硬化 \\
\hline RNA polymerase I & DNA（転写時） & 210-11KD & $<5 \%$ & び漫性皮膚硬化, 強皮症腎 \\
\hline \multicolumn{5}{|c|}{ 多発性筋炎/皮膚笳炎 (PM/DM) } \\
\hline JO- $7 * *$ & tRNA & $55 K D$ & $20 \sim 30 \%$ & 肺線維症 \\
\hline $\mathrm{PL}-7 * *$ & tRNA & 80KD & $<5 \%$ & 肺線維症 \\
\hline PL-12 ** & tRNA & $110 K D$ & $<5 \%$ & 肺線維症 \\
\hline SRP & 7SL-RNA & $\begin{array}{l}72 \mathrm{~K}, 68 \mathrm{~K}, 54 \mathrm{~K}, 19 \mathrm{~K}, \\
14 \mathrm{~K}, 9 \mathrm{~K}\end{array}$ & $<5 \%$ & 重症筋炎, 皮膚筋炎 \\
\hline MI-2 & DNA & $\begin{array}{l}240 \mathrm{~K}, 190 \mathrm{~K}, 150 \mathrm{~K}, \\
65 \mathrm{~K}, 63 \mathrm{~K}, 30 \mathrm{~K}\end{array}$ & $5 \sim 10 \%$ & 皮膚筋炎 \\
\hline \multicolumn{5}{|l|}{ 関節リウマチ（RA） } \\
\hline リウマトイド因子 & & ヒトIgG Fc & $80 \%$ & \\
\hline シトルリン化抗原 & & CCP,フィブリン & $50 \sim 90 \%$ & \\
\hline カルパスタチン & & $73 K D$ & $50 \%$ & \\
\hline \multicolumn{5}{|l|}{ Sjögren 症候群 (SjS) } \\
\hline SS-A ** & hY1-hY5 & 52KD, 60KD & $70 \%$ & $\begin{array}{l}\text { C4 欠損, 新生児儿一プス } \\
\text { 環状紅玟, 乾燥症候群 }\end{array}$ \\
\hline SS-B & $\begin{array}{l}\text { hY1-hY5, RNAPol } \\
\text { II 転写 RNA }\end{array}$ & $50 K D$ & $40 \%$ & 乾燥症候群 \\
\hline $\begin{array}{c}\alpha-\text { フォドリン } \\
\text { 膠原病重複症候群 }\end{array}$ & & $120 \mathrm{~K}$ & $90 \%$ & 乾燥症候群 \\
\hline U R RNP & U1 RNA & $\begin{array}{l}\text { 7OKD, A, B/B', C, D, E, } \\
F, G\end{array}$ & $\begin{array}{l}100 \% \\
\text { (MCTD) }\end{array}$ & $\begin{array}{l}\text { Raynaud 現象, 肺線維症, } \\
\text { 肺高血圧症 }\end{array}$ \\
\hline U2 RNP & U2 RNA & $A^{\prime}, B^{\prime \prime}, B^{\prime} / B, D, E, F$ & $<5 \%$ & $P M+S S c$ \\
\hline $\mathrm{Ku}$ & DNA & 70KD, 80KD & $25 \%$ & $P M+S S c$ \\
\hline PM-Scl $* * *$ & & $110-20 K$ & $10 \%$ & $P M+S s c$ \\
\hline
\end{tabular}

*細胞質亡核小体， **細胞質， ***核小体亡核質にそれぞれ局在する 
ボゾームRNAの前駆体やそれを合成する酵素な どのように核小体に存在しているものがある. この各抗原の核内分布が後述する蛍光抗体法 (IF) における染色像に直接関与している.

これらの自己抗原に共通する構造上の特徵は, DNAおよびRNAなどの核酸と結合するものが多 く, 単一の蛋白として存在することょりも複数 の蛋白と結合した複合体を形成している点にあ る. 抗原の構造は臨床的には意味のない事項の ように思われるかもしれない.しかし，一連の 抗原が核酸などに結合する複合体である実体を 知ることは, 後述する各検出法の利点や問題点, さらに診断上，ある一つの抗原自体に対する反 応性の有無に加え, その抗原を構成するどの蛋 白に対する抗体が存在しているかということが 問題となることを理解する上で重要である ${ }^{1 \sim 3)}$.

\section{ANAの検出方法とその特徵}

ANAの検出法にはIFをはじめ, 二重免疫拡散 法 (DID), 受身赤血球凝集反応 (PHA), ラジ オイムノアッセイ (RIA), enzyme-linked-immunosorbent-assay (ELISA ; EIA), 免疫ブロット 法（IB）および免疫沈降法（IP）などがあり， 検出しようとする抗体や目的によって適切な方 法を選択する必要がある, 以下, 各方法の概略 とその特徵について述べる.

\section{1) $\mathrm{IF}$}

本法では通常, エタノールなどで固定された 核材に, PBSなどで倍々希釈した被検血清を反応 させ, 洗浄後, 蛍光色素を標識した抗ヒト $\gamma$-グロ ブリン抗体を反応させ, 再度洗浄後, 細胞核の 染色を蛍光顕微鏡で観察する蛍光抗体間接法が 用いられている. 抗体の力価は蛍光を認めた最 終希釈倍を持って表現し, その染色像が報告さ れる. IFに拈ける染色像は抗体が反応している 抗原によって異なっている。 以前は核材として ニワトリの赤血球，マウス，ラットなどの肝お よび腎組織切片が用いられてきたが, 現在は
HEp-2 細胞を中心とするヒト由来の培養細胞が 用いられている。 これには, 染色パターンも詳 細に観察でき, 種々の細胞周期の細胞が混在し ているために, 細胞周期特異的抗原に対する抗 体の検出も可能となるなどの利点がある.さら に, ヒト，猿，豚などの組織には存在するが, マウスやラットの細胞には含有されていないSSAのような種特異的抗原に対する抗体の検出にも 有用である。

図 1 にHEp-2 細胞を核材として用いたIFの基 本染色パターンを示す. homogeneous型（均質 型；A), peripheral型 (辺縁型；B), speckled 型(斑紋型；C), およびnucleolar型（核小体型； D）の 4 つの染色像に加え, discrete speckled 型（粒状斑紋型；E）ならびにPCNA（proliferating cell nuclear antigen）型（散在斑紋型； F） などの染色像が認められる。均質型は抗ヒスト ン抗体 (もしくは抗DNP抗体), 辺縁型は抗DNA 抗体, 斑紋型は抗U1 RNPやSm抗体などのENA に対する抗体, 核小体型はリボゾームRNAの前 駆体やそれを処理する酵素などに対する抗体, さらに粒状斑紋型は抗セントロメア抗体による. PCNA型は核質内への出現が細胞周期に強く関連 している抗原に対する抗体で, 抗PCNA抗体の場 合はS期の細胞を特異的に染色する.

\section{2) DID}

本法は, ENAに対する抗体の検出に用いられ る。家鬼胸腺のPBS抽出液を抗原源とし， 0.4 $0.6 \%$ の寒天板内で被検血清および各抗体の標準 血清を反応させる．標準血清の沈降線との同一 性を検討することにより各抗体の有無を判定す る. DIDはELISAなどに比較すると感度は低いも のの, 疾患への特異性が高く, その手技が簡便 で定性及び半定量法として優れていることから 今でも広く用いられている.

\section{3) $\mathrm{PHA}$}

仔牛胸腺より抽出したENAをRNaseで処理後, RNAase処理および未処理の抗原を感作したヒツ ジ赤血球を用意し，被検血清との凝集反応にて 

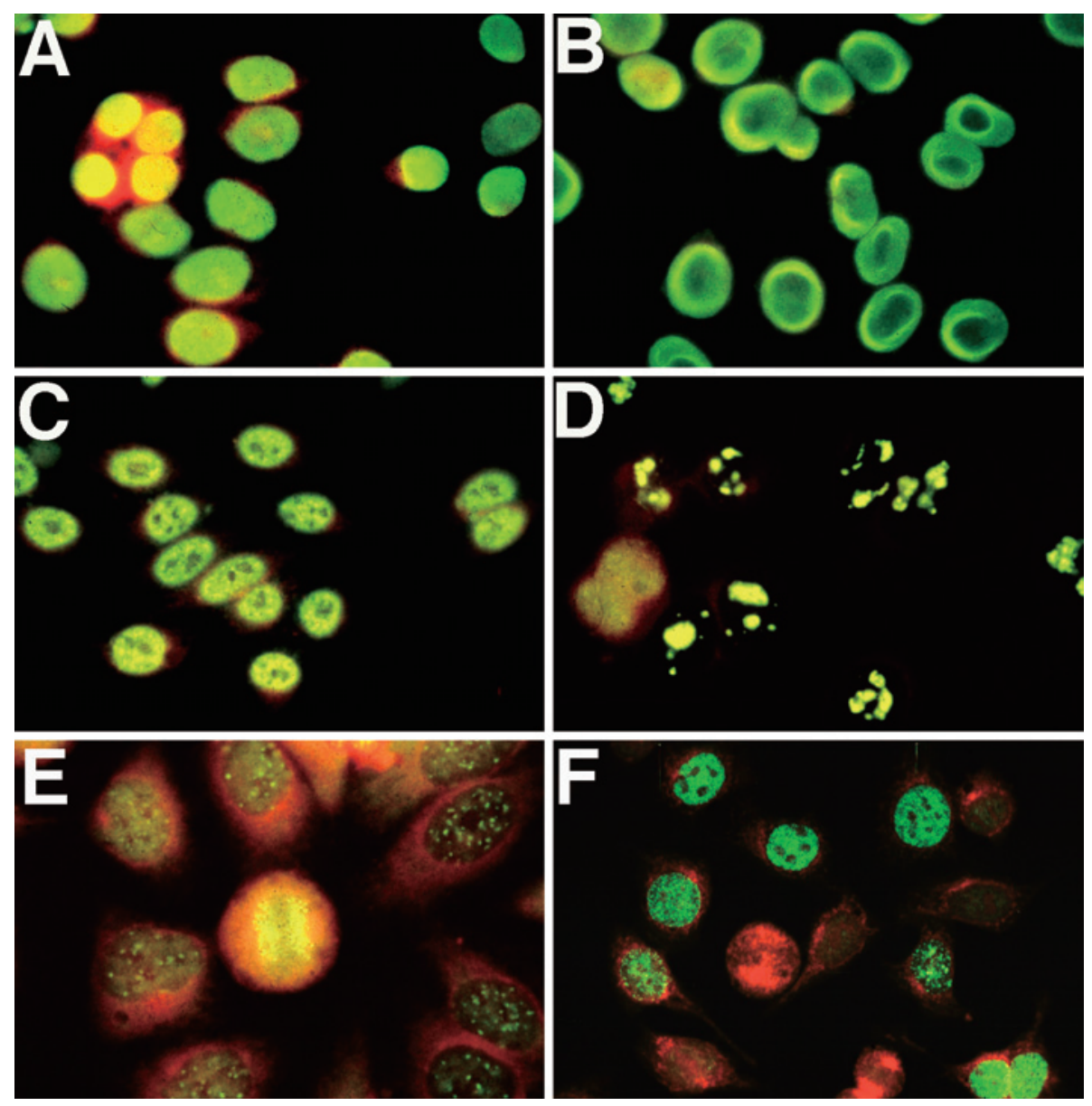

図 1. HEp-2 細胞を核材とした IF による染色像

抗体を検出する. RNaseによって抗原性が破壊さ れるRNase感受性ENA抗原に対する抗体は抗U 1 RNP抗体, 抵抗性を示す抗原に対する抗体は抗 Sm抗体である確立が高い。しかし, 同様の反応 性を有する他のANAもあるので, DIDなどの定 性的検査による確認が必要となり, 今日ではほ とんど用いられていない.

\section{4）RIAおよびELISA}

RIAとELISAは前者がラジオアイソトープ, 後 者がペルオキシダーゼなどの酵素を用いるが, 基本的に両者ともに精製抗原を用い, 特異抗原 に対する抗体の定量的測定法という点で共通し ている.
RIAは放射性物質を用いることから次第に ELISAにとって代わられつつあるが, 抗dsDNA 抗体の測定に現在も用いられている。これには いくつか異なる方法があるが，まず第一は，硫 安沈澱法 (Farr assay) で, ラジオアイソトープ を標識したdsDNAに, 被検血清を反応させ, 抗 原と抗体の免疫複合体を硫安で沈澱させ，その 放射活性を測定して抗体量を検出する。一方, ミリポアフィルター法では免疫複合体をミリポ アフィルター上に捉え，この放射活性を測定す る.これらは液相法の代表的なものであるが, 固相法ではマイクロプレートもしくはポリスタ イレンチューブにdsDNAを吸着させ, 被検血清 
と反応させる. その後, 結合した抗体をラジオ アイソトープ標識 2 次抗体で検出し, チューブ に残存した放射活性を測定する事によって抗体 量を検出する。この固相法では免疫グリブリン クラス別に抗体を検出することが可能となる.

ELISAは基本的にRIAの個相法と同一である が，酵素標識した 2 次抗体を用い，発色反応に より抗体量を検出する方法である。本法は，ラ ジオアイソトープを使用しないので手軽に行う ことが出来る。また，最近は異なる発色をする ビーズに抗原を固相化し，一度に複数の抗体を 同時に測定するシステムも開発されている ${ }^{4)}$.ま た，近年，分子生物学的手法を用いた抗原の調 整システムが導入され，抗体への特異性や感度 も高くなり，定量的にも優れたシステムが開発 されている31).しかし，感度が鋭敏であるが故に 疾患特性が低下したり，また抗原分子の一部の 蛋白を用いることなどに起因する新たな問題も 指摘されている3).

5) $\mathrm{IB}$

本法では, 抗原をSDS-ポリアクリルアミド電 気泳動で泳動後, ニトロセルロース紙に転写し, これに被検血清を反応させたのち, 酵素もしく はラジオアイソトープ標識抗ヒト $\gamma$ グロブリン 2 次抗体を反応させ，各抗体が反応するポリペプ チドを検出する．表に示すように，多くの自己 抗原は複数の蛋白から構成されており, 同じ抗 原に対する抗体でもその各構成蛋白に対する反 応性の相違が診断上問題となるときに有用な方 法となる.

\section{6) IP}

IPは抗U1 RNPおよびSm抗体のような $\mathrm{snRNP}$ （small nuclearRNP）や，PMにしばしば認めら れるt-RNA合成酵素に対する抗体の検出に利用さ れ，鋭敏で高い特異性を有している. 通常, Hela 細胞などの培養細胞に ${ }^{32} \mathrm{p}$ 取り込ませた細胞抽 出液, もしくは無標識の抽出液を血清と反応さ せ, その免疫沈降物からRNAを抽出し, 電気泳 動後, 前者ではオートラジオグラフィー, 後者
では銀染色で各UシリーズRNPの沈降などを確認 する。ルーチンに用いられる方法ではないが, 抗U2 RNP抗体などはこの方法のみによって測定 可能となる ${ }^{5)}$.

\section{ANA検査の進め方}

膠原病などの疾患を疑い, ANAを検索する場 合, そのスクリーニング法としてはIFが最も優 れている. この際, 抗SS-A抗体や, 抗Jo-1 抗体 などの抗アミノアシールtRNA合成酵素に対する 抗体の対応抗原は, 細胞質に存在するので, こ れらの抗体が単独で存在しているとIFでは“ANA 陰性”と判定されることもあるので注意を要す る.また, 最近, 検査センターによっては, 種々 の疾患特異的自己抗体の対応抗原に加え, 一本 鎖DNAなどを混合して感作したプレートを用い たELISAによるANA測定キットを用いている所 もある ${ }^{6)}$.このようなキットでは抗核小体抗体単 独陽性血清などは陰性となるので留意する。

IFによるANAはSLEでは $90 \%$ 以上で陽性とな り，診断基準の一項目を満たすことになる。し かし，ANAは他の膠原病でも高率に検出され， さらに，最近，HEp-2 を核材として用いるよう になってからその感度が上昇し，正常人での陽 性率も上昇した。実際，国際抗核抗体標準委員 会の調査では，正常人でも 40 倍で $31.7 \%, 80$ 倍で $13.3 \%, 160$ 倍では $5.0 \%$ が陽性となること が明らかにされている7)。これらの正常人ANA の対応抗原はDFS70 など, 患者血清中のANA とは異なることが示されているものの ${ }^{8)}$, 現在の 所一般臨床医家がそれを測定する事は困難であ るので, 臨床像をよく勘案し, 適切な診断を進 めていくことが求められている.

図 2 に各疾患特異抗体の同定を進めて行くフ ローチャートを示す．IFの染色像に応じて予測 される抗体の同定を行うが，各疾患特異抗体の 測定法は対応抗原によって異なっており，適切 な方法を選択する必要がある. 抗dsDNA抗体の 


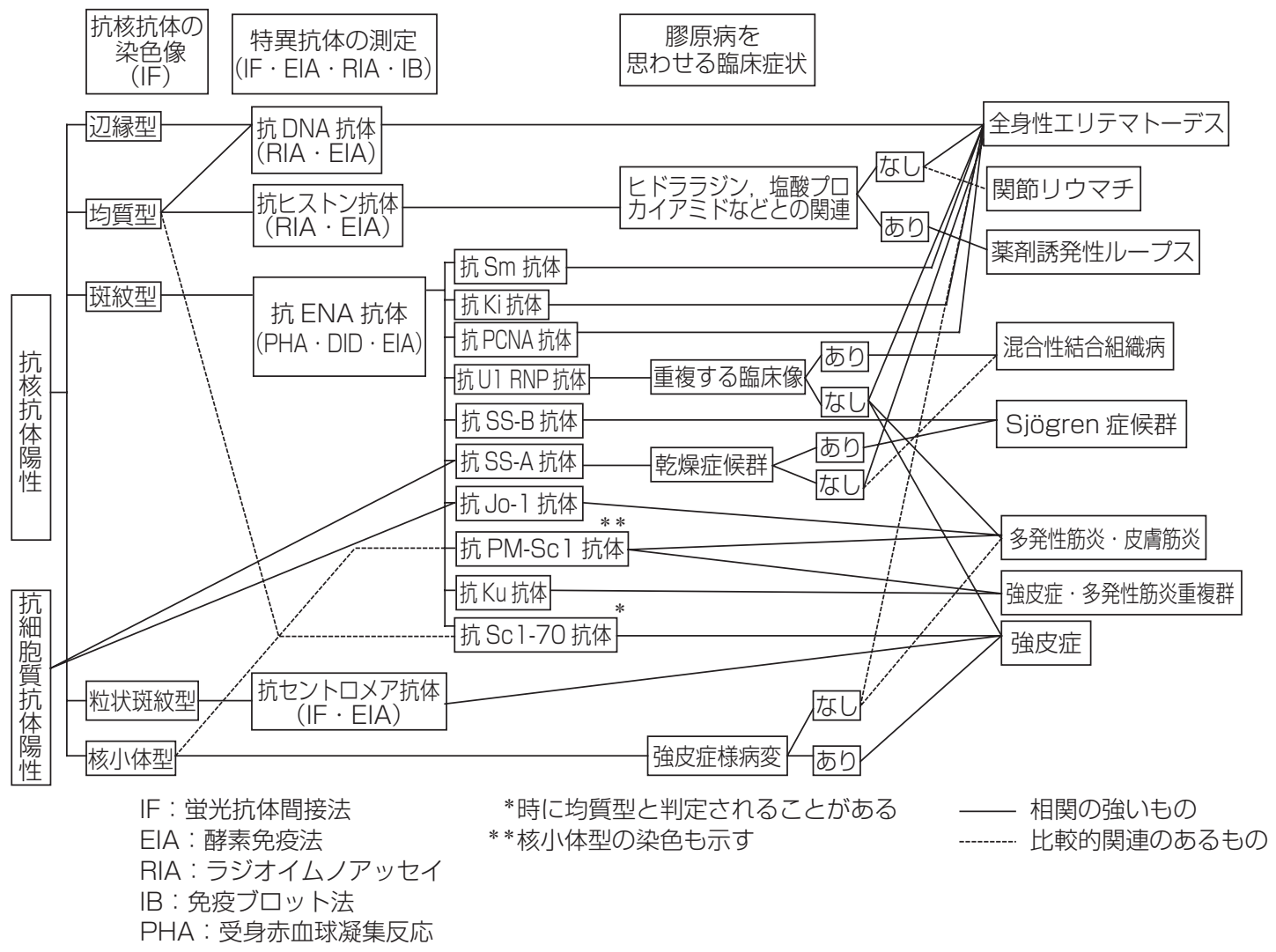

図 2. ANA 検査のフローチャート

測定にはRIAやELISA, 一連の可溶性各抗原の測 定や抗Jo-1 抗体および抗SS-A抗体の測定にはリ コンビナント抗原を用いたELISAが汎用されて いる. ELISAは一般的に感度や特異性に優れて いるが, 感度の高さ故に疾患特異性が低くなっ ているものや，またリコンビナント抗原の構造 的問題から一部陰性となる場合もある. 特にU 1 RNP抗体についてはU1 RNAと 70Kd蛋白の結 合によってもたらされる特異な立体構造を認識 する抗体が約 $10 \%$ 程度認められ6), キットによっ てはこれを検出する事はできないので，疑問が ある場合にはDIDなどで再検する。

\section{ANAの臨床的意義}

ANAには前述の如く疾患への特異性を認める
ものがあり，その診断に有用である(表).また， 特異な病像との相関を示すものもあり, その抗 体を有する患者の予後なども予測可能なことも ある(表). 疾患特異性の高い抗体としては, SLE の抗ds-DNA及びSm抗体, SjSの抗SS-B抗体, 強 皮症の抗Topoisomerase I(Scl-70) 抗体, CREST 症候群の抗セントロメア抗体, PM/DMの抗Jo-1 及びMi抗体, PSS-PM重複症候群の抗PM-Scl （PM-1）およびKu抗体などが知られている. 抗 U1 RNP及びSS-A抗体は，それぞれMCTD, SjS にて高率に検出されるが, 他の膠原病でも比較 的高率に検出されることに留意する必要がある.

病像との相関では, 抗U1 RNP抗体はMCTD の特徵的症状として良く知られるRaynaud現象, 手指の腫脹および肺高血圧症などの病像と良く 相関し, 腎症を発症してもその程度が軽症であ 


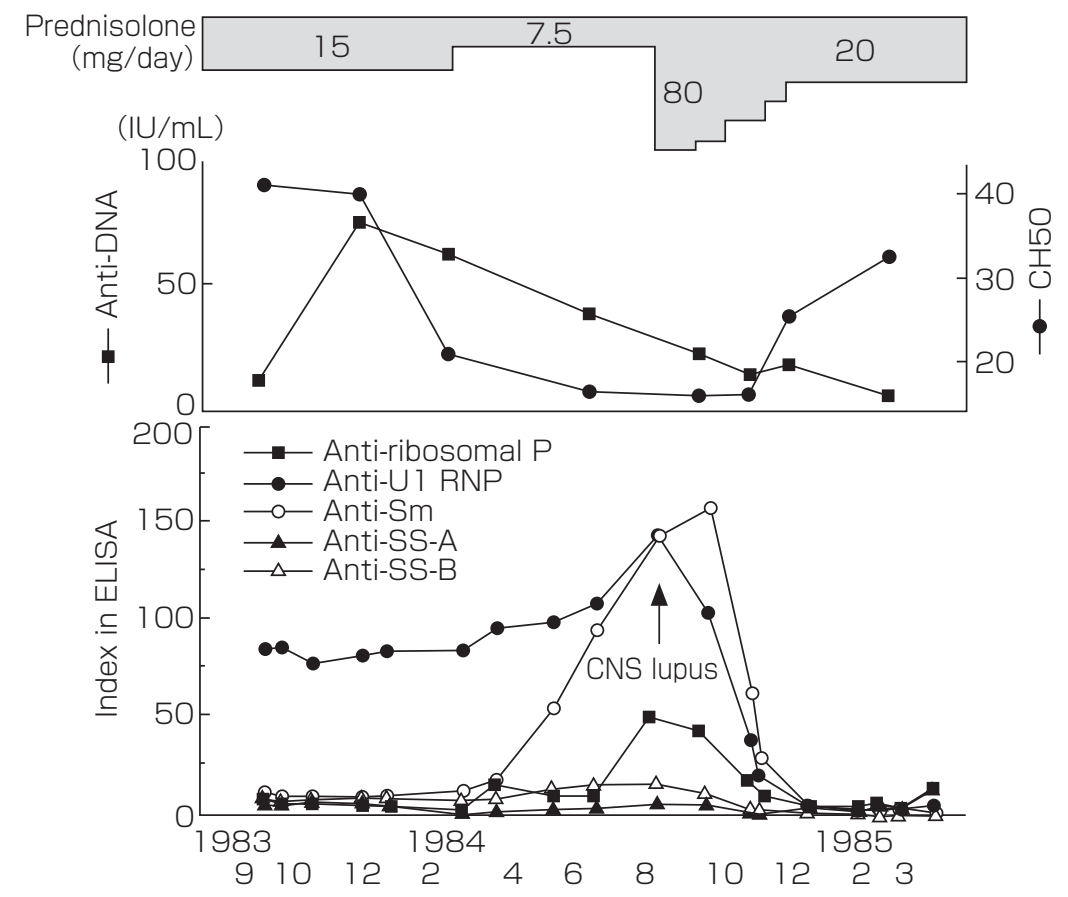

図 3. SLE 患者の臨床経過と ANA 抗体価

この症例は抗U1 RNP 抗体単独高值で MCTD と診断されていたが, CNS ループスに相関する抗 Sm 抗体が途中から陽性となり, 抗体価が上昇し, さら に抗リボゾームP抗体も加わって CNSループスを発症した. 一般に抗 dsDNA 抗体は腎症と相関するが CNS ループスとは相関しないことが多い.

るなどの特徴がある.また, 強皮症では, 抗Scl70 抗体陽性例は皮膚硬化の範囲が広く, 肺線維 症を合併しやすいなどの特徵がある。しかし， これに対して抗セントロメア抗体陽性例は，ほ とんどの症例でCREST型の病像を示し, 皮膚硬 化の範囲もせまい. また, PMのアミノアシール tRNA合成酵素に対する抗体は肺線維症に高い相 関を有する。その他の相関については表を参照 されたいが, これらはしばしば患者の予後を予 測する上で有用である.

また，IBを用いて同一抗原の各構成蛋白への 反応性を検討すると, MCTD患者由来の抗UIRNP 抗体はSLE患者のそれに比較して 70kDa蛋白やA 蛋白上のB”蛋白と交叉反応を有するエピトープ に有意に高率に反応することや ${ }^{1)}, \mathrm{SLEやSjSの母}$ 親から生まれる新生児の先天性完全房室ブロッ
クは $60 \mathrm{kD}$ に加え， $52 \mathrm{kD}$ 蛋白に反応する抗SSA抗体が有意に高率に認められることなどが報告 されている1). 従って, 妊娠のリスクの評価には IBによる分析が重要な意味を持っている.

一方, 抗dsDNA抗体などの特定の抗体は, 血 清補体価とともに腎症の活動性と良く相関し, 治療の指標として有用な情報を提供する。しか し, この抗dsDNA抗体も他の病態とは必ずしも 相関しないし(図 3), 一般的にはANAの抗体価 は疾患の活動性とは相関しないので，あくまで も, 臨床症状の評価を中心に据え, 抗体価自体 を目標に治療を行ってはならない.

おわりに

ANAは膠原病に高い感度を有すものの, 必ず 
しも特異的ではない.この点を良く理解し, 臨 床症状を勘案しながら, 検査の選択と結果の解 釈を適切に行う事が求められている.

\section{文献}

1）高崎芳成：自己抗体とその臨床的意義, Annual Review 免疫 1992. 菊地浩吉, 他編. 中外医学社, 東京, 1992, 266-277.

2) Tan EM:Antinuclear antibodies: Diagnostic markers for autoimmundiseases and probes for cell biology. Adv Immunol 44 : 93-151, 1989.

3) Murakami A, et al: A new conformational epitope generated by the binding of recombinant 70-kd and U1 RNA to anti-U1 RNP autoantibodies in sers from patients with mixed connective tissue disaese. Arthritis Rheum 46: 3273-3282, 2002.

4) Fritzler MJ : Advances and applications of multiplexed diagnostic technologies in autoimmune diseases. Lupus $15: 422-427,2006$.

5）高崎芳成：抗U1 RNP抗体と抗U2 RNP抗体. 日本臨床 63 (増刊号 7) : 512-514, 2005.

6）浅沼浩子,他：抗核抗体のスクリーニング法の新たな試 み一ELISAによる疾患標識抗体のスクリーニング法の試 み一. Jpn J Clin Immun 20:417-427, 1997.

7) Tan EM, et al: Range of antinuclear antibodies in "Healthy" individuals. Arthritis Rheum 40 : 1601-1611, 1997.

8) Watanabe A, et al : Anti-DFS70 antibodies in 579 healthy hospital workers. Arthritis Rheum 50 : 892-900, 2004. 